\title{
Identity Crisis in Cormac McCarthy's All the Pretty Horses
}

\author{
Hayder A. K. Gebreen \\ College of Education, University of Al-Qadisiya, Iraq \\ E-mail: hgebreen@yahoo.com
}

Doi:10.7575/aiac.alls.v.7n.2p.90

URL: http://dx.doi.org/10.7575/aiac.alls.v.7n.2p.90
Received: 10/11/2015

Accepted: 16/01/2016

\begin{abstract}
The issue of identity is one of the main issues that encounters man in each culture. Identity is a set of behaviors, emotions, and thought patterns which are unique to every individual that define him as a member of a certain group. Identity is shaped by race, ethnicity, religious beliefs, language, physical features, childhood experiences, sexual preferences and culture. Moreover, identity is usually recognized during adolescence or early adulthood in which both positive and negative features are essential in the development of individual identity. However, an identity crisis is the failure to establish identity during that age. In addition, an identity crisis is not only concerned with matters such as ethnicity or religion as it is also concerned with inner conflicts, search for identity, west vs. east, old Vs. modern. The diversity of identity in the American culture is expressed in many literary works by contemporary American writers who depict characters' search of their psychological and cultural identity. Among those contemporary writers is Cormac McCarthy (1933-) whose All the Pretty Horses (1992) tackles this quest for identity as its basic theme, both psychologically and culturally. This paper is an attempt to investigate both dimensions of the quest in this novel as being one of McCarthy's masterpieces.
\end{abstract}

Keywords: Identity, Identity Crisis, Cultural Criticism, Contemporary American fiction

\section{Definitions}

The term 'identity' is widely used in the fields of cultural studies, literary theory, politics, sociology, and psychology, to name but a few. However, it is not easy to provide a single, straightforward definition of this term. Therefore, one can examine a range of definitions that come under this umbrella term. But individuals have psychosocial growth beside the historical origins in earlier psychosocial stages. In its broader sense, identity refers to "a person's sense of continuity with the past that constitutes the foundation for a meaningful personal and social present, which in turn proposes directions for future" (Deaux, 2000, p. 222).

Erik Erikson devised the term 'identity crisis' to label the doubt, even unease, which adolescents might sense as they realize that they are no longer children. They turn out to be confused about their present and future roles in life. Another possible anxiety could result from the passing insecurity and confusion that adolescents feel as they try a range of choices. The concept of identity crisis does not indicate a coming disaster, but rather a "critical turning point in the life history of an individual, in which development can only move forward by taking a new directional course," (Hopkins, 2000 , p. 234). The concept 'identity crisis' defines a young individual's quest for identity, but youths who in a lively exploration of identity are more motivating than disappointing. The most painful thing about identity crisis is the failure to establish an identity. Then, individuals might sense an actual identity crisis (Shaffer, 2007, p. 453).

\section{Introduction}

All the Pretty Horses, henceforth (Horses), has been credited as presenting a new cowboy protagonist who is coming into conflict and ruin as he rides through the landscape. Although he is 16 years old, John Grady Cole reflects the cowboy culture of the West, the novel depicts the frontier's modernization. The protagonist, John Grady Cole is conscious that something is 'happing to country' (Inness, 2000, p. 6).

The novel records the life of John Grady Cole and his disinheritance from the ancestral ranching dream and his following quest for that dream in Mexico. He refuses to abandon his cowboy self-identity and he appears in the novel as the mythical cowboy who in search of a lost land. It is set in the wilderness of the American Southwest and Northern Mexico, where modern technology and military activities have ruined the pastoral frontier life that is already disappearing from John Grady after his grandfather's death.

Horses begins on 13 September 1949, with the burial of John Grady's maternal grandfather in San Angelo, Texas, the latter's passing marks the loss of the family ranch. With his grandfather's death, the last of the line of deep commitment to the land ended, as John Grady's mother sells it for an oil company. Then, he travels on a horseback to Mexico to achieve his pastoral ambition as a trainer of wild horses, and he also finds and loses a kind of passionate love. He and his friend Rawlins also experience the bloody realities of life there.

The novel also tackles the disappearance of the cowboy culture in the revival of a progressively urbanized American culture, and the efforts of John Grady to resist it. He does so by heading south the borders towards Mexico, where he 
hopes to retain the cowboy lifestyle. However, what John Grady realizes there is also a changing world. This modern catastrophe meant the fading of the cowboy lifestyle. Though it still physically exists, by 1951 the frontier faded, and cowboy culture faded with its frontier. It is no longer a pastoral land in the pressures of urbanization and industrialization. This erasure of frontier open space was an identity crisis for those cowboys (Rodriguez, 2014, p. 3).

One can highlight John Grady's identity crisis as he fails to create a stable identity. Phillip Snyder (2001) argues that John Grady cannot prove that he is able to create a stable identity. Snyder's analysis concentrates on his development that defines his identity as 'cowboy', and he claims that the "central issue" is "the shifting locus of American cowboy identity and the displacement of the vocation within which that identity and its attendant values once flourished". Although Snyder concentrates on the confusion status of the cowboy identity, he clarifies the protagonists' greatest key development is their ability to fit their 'cowboy identities to "a new western environment" (p. 198).

McCarthy shows how individuals construct an identity that consists of 'commitments and explorations' which establish the essential beliefs that let individuals spot their situation in the world. Individuals shape their primary identity which informs their sense of self, but as adolescents acquire new information, their perspectives increase to contain an understanding of past crises.

\section{Adolescent at Home}

The opening paragraph of the novel shows a sense of identity crisis in its portrayal of John Grady when he enters the house which contain his grandfather's corpse. There is a reflection of him in the mirror of the portrait of his dead ancestors. The portrait depicts a culture which realizes its present in terms of its past, a culture which attempts to reestablish an identity. The novel starts as follows: "The candleflame and the image of the candleflame caught in the pierglass twisted and righted when he entered the hall and again when he shut the door" (Horses 1).

David Dary (1989) in his treatment of the cowboy culture and its golden age in the American West said that it vanished in the mid- $20^{\text {th }}$ century. Further, he states that this cowboy culture was still shining intensely in the minds of Americans and it still breaks through the American culture, it is not the culture of the real $19^{\text {th }}$ century cowboys, but rather, it is a combination of fact and imagination. After they try without success to find a place for themselves in Mexico (the original paradise of cowboys), McCarthy's cowboys who work in the mid of the $20^{\text {th }}$ century, are in danger of extinction by the crisis of loss and familial displacement. Those cowboy characters need to adjust themselves into a new western environment or die (p. 199).

In order to deserve and be fully worthy of the name of the Grady family, John must seek out heroic actions and must face the crises of loss that may come with these actions. McCarthy presents John Grady's mythical ancestry who have experienced cruel deaths when they were young. These deaths differ expressively from his father's and grandfather's deaths:

His grandfather was the oldest of eight boys and the only one to live past the age of twenty-five. They were drowned, shot, kicked by horses. They perished in fires. They seemed to fear only dying in bed (Horses 4).

The grandfather's funeral signifies the end of the Grady name as a result of the violence of the Old West and old age, a name which is "buried with that old man" (Horses 4). This name has left John Grady both connected and at the same time dislocated from the ancestral line because he carries the family name, but from the mother's side. His psychological crisis of the loss of his mentor in life is indicated here. He remains the sole inheritor who carries the name that is already buried and this is something which increases his confusion (Morrison, 1999, p. 176).

McCarthy signals the grandfather's death as the gradual end of the American plains where ranchers sell their lands for oil companies. This is a cultural crisis in which where an entire history of people ends up, among generation of young cowboys like John Grady who will be disconnected with their traditions. The changing landscape and the death of men in wars add greatly to this crisis (Scoones, 2001, p. 142).

Because the cowboy culture is diminishing, John Grady must engage with other cultures, such as the Mexican ones, in order to survive this crisis. In addition, the identity of a culture, Derrida argues, is a way of being self-differentiating by the culture of individuals, nations, language, ethics... etc. However, both critics, Gail Moore Morrison and Dianne C. Luce stress the "individuality" of John Grady's development in his quest to recover the lost ranching life in the fallen world of the West. They both argue for the ultimate usefulness of that quest at least in his self-actualization, but only Luce stresses his self-development (as cited in Snyder, 2001, p. 203). It appears what they have said is true, especially if one noticed that John Grady ignored all the warnings concerning his relationship with the Mexican girl Alejandra.

John Grady's grandfather's death and the loss of the family's ranch serve as a catalyst for the transition of his identity which is based on his family influences, for a new self-identification. Then, this crisis threatens John Grady's major beliefs and isolates him from the life of a cowboy so as to settle him down. This is his 'identity crisis' which affects the process of his development and leaves him confused due to the experiences that contradict with his beliefs. To build an identity, one must settle the present situation with one's past beliefs and this must be repeated throughout an individual's life. Thus, this process of development aims to state an individual ethical orientation and self-conception to fit his present (Jackson, 2010, p. 19).

Moreover, the introduction of technology into the wilderness is so disturbing to John Grady. The use of the machine into the Old West disrupts John Grady's fixed sense of culture and of himself. Thus, looking at this relationship between landscape and identity, the transformation of the Old West through fences or trains, interrupts John Grady's dream to 
live the cowboy life of the Old West (Cameron, 2011, p. 49). Therefore, the solution is to search for a landscape that is really connected with their deep desire for a stable, recognizable identity but technology as it is represented here by the train as:

Some supplicant to the darkness over them all and he stood there for a long time. As he turned to go he heard the train... It comes boring out of the east like some ribald satellite of the coming sun howling and bellowing in the distance and the long light of the headlamp running through the tangled mesquite brakes and creating out of the night the endless fence-line down the dead straight right of the way and sucking it back again wire and post mile on mile into the darkness (Horses 1).

The passing of the train through the landscape from the East to the West marks the end of open spaces for cowboys. A century passed since cowboys wandered without fences, or trains in the plains. John Grady is influenced by that cowboy culture and its vast space to roam. In that patriarchal culture of cowboys, his divorced mother is the inheritor of a long line of ranching men, but she prefers a more civilized life in San Antonio rather than the life on a ranch in the frontier (Hage, 2010, p. 34).

The novel shares some of the traditional heroic cowboy codes and sets the tone for the exploration of these codes in the modern world. The novel starts with what the critic Gail Moore Morrison depicts as "John Grady Cole's expulsion from paradise" as he loses the family ranch, which have been sold by his mother upon the death of her father. Despite the boy's efforts to preserve it, the ranch is lost, which makes him alienated as the Indians Comanche were alienated when their lands were taken from them (p. 176).

John Grady's identity crisis is also embodied in the arrival of technology, the vanished Indian tribes, his grandfather's death and the terminal line of frontier ancestors, the lost culture of the Old West, in the selling the family's ranch and his awareness of his father's illness and despair. As he was riding along an old road once used by Comanche Indian, John Grady invokes a vision:

That lost nation come down out of the north with their faces chalked and their long hair plaited and each armed for war which was their life and the women and children and women with children at their breasts all pledged in blood and redeemable in blood only... nation and ghost of nation passing in a soft chorale across the mineral waste to darkness bearing lost to all history and remembrance like a grail the sum of their secular and transitory and violent lives (Horses 3 ).

McCarthy compares the cowboys to those lost Native nations of the West in which they were extinct with the coming of the Anglo cowboys to the area. Then, he suggests that it is time for cowboys and their culture to extinct as well. Besides, he describes John Grady as "a man come to the end of something." That something may be taken as his way of life which is approaching the end.

As he rides his horse on the old Comanche Indian road, John Grady feels the souls of the Native Indian cultures that formerly rode this road and now his cowboy way of life is dying just as the Native's culture. It is these continuous comparisons between the perished and the vanishing cultures that McCarthy cares about, he depicts those cultures on the border as they moved towards extinction (Hage, 2010, p. 51).

Although McCarthy is referring explicitly to the Comanche, their passing violent lives could be compared to any race, even if it was an Anglo American such as John Grady. By doing this, McCarthy identifies his hero's culture with those of the Native one (King, 2012, p. 120). This points out the link between the Comanche Indians and the lost cowboy culture of the Old West. McCarthy highlights this link by describing John Grady as being "like a man come to end of something" (Horses 3).

On his way to the city of San Antonio where his mother lives, John Grady went with an old man who was driving a truck. The old man talks to him, but John Grady didn't talk that much and the old man asks him: "You dont talk much, do you?" John Grady answers "Not a whole lot." John Grady's personality speaks for cowboy culture in which cowboys are expected to reflect the strong, silent stereotype of the Western hero (Snyder, 2001, p. 223).

As the funeral of John Grady's grandfather marks the fading of the cowboy, his cultural crisis is reinforced by his parents' denial of the cowboy lifestyle in favor of city life. His father lives alone, his experiences as a prisoner for the Japanese in WW II have left him unable to function in society or to be of much use to his son. His mother is a stage actress in San Antonio. John Grady's interaction with Mr. Franklin, the family lawyer, shows his unfulfilled efforts at invoking the law due to his young age:

Son, not everybody thinks that life on a cattle ranch in west Texas is the second best thing to dyin and goin to heaven. She [John's mother] dont want to live out there, that's all (Horses 13).

John Grady's mother is the character in the novel who shows the effects of modernity and how could it interrupts John Grady's dream of a pastoral life as she rejects his wish to look after the ranch himself. John Grady attempts to understand his mother's choice of life by watching one of her plays, but he fails to drive from her play anything "to tell him about the way the world was or was becoming" (Horses 17).

In the West, the new way of life is taking the place of the old, but the old way of life still echoes. Richard Slotkin states 
that some central change of the story structure of a myth indicates some intense change in the culture that creates it. Here, the wounded link is connecting America's mythical past with its troubled present. This myth is the vicious birth of a national icon of the West that formulated protagonists from "scalp hunters and Indian killers" (as cited in Spurgeon, 2009, p. 104).

John Grady wishes to have an established identity, but the crisis of loss of the ranch defies his capacity to catch consistency concerning his past and his current situation. In addition, the collapse of his family leads him to doubt the views of other individuals such as remarking the sale of the ranch as a betrayal by his mother. At this point, he perceives the adults in his life as absent, dead, and powerless. As he needs self-education, he decides to take a journey to Mexico, which is going to help him to form the basis for his identity.

In Western novels, cowboys ride in the yearning for that horse culture that they have lost. The crisis of loss of the ranch marks a local loss of domesticity and wilderness and John Grady has either to live in the city of San Antonio and abandoning the wilderness and its vast lands or turning into a homeless nomad. Then, McCarthy's novel is placed in a critical moment in the development of a national identity, the moment where the Mexican desert lands are combined into what has turned out to be the American Southwest. The novel focuses on the dispossession of the Anglo ranching culture by the oil industry and military activities (Ellis, 2006, p. 202).

John Grady strives to settle his wish of an ideal pastoral lifestyle which leads to his crisis. However, in their last ride together, his father is described as having a depressed outlook that has been transferred in some form to his son as he views the pastoral landscape (Guillemin, 2001, p. 95). His father assures his self-perception and offers him a saddle, as a way of confirming his cowboy identity. He tells his son while riding the horse that the country and its culture are changing.

McCarthy reflects the changes in the Old West through John Grady's father who sees a vast change occurring there. This change in the nature of the land affects their way of life so that the father looks at the land as if he might not see it again. Then, McCarthy assures John Grady's cowboy nature when he describes him as "The boy who rode slightly before him sat a horse not only as if he'd been born to it."

The biggest effect of the crisis in the cowboy's everyday life is the destruction of security. His father compared the ranching culture to the Comanche two hundred years ago and acknowledges the cowboys' demise by the same forces that legitimized their presence in the first place. Then, it is not surprising that John Grady and his father compare themselves to the Comanche Indian. The attraction of Mexico south of the border is the only place remaining of the ranching culture that gives meaning for them. Mexicans and the Indians who live there represent for them a mode of non-instrumental existence of which any cowboy dream of and that they come to identify themselves with (Beck, 2009, p. 134).

Through the changes of the countryside, John Grady's father expresses his beliefs about the changing world of cowboys and about himself. His father projects the cowboy sense of crisis through the changing country itself. McCarthy suggests their sense of crisis:

The last thing his father said was that the country would never be the same. People dont feel safe no more. We're like the Comanche was two hundred years ago. We dont know what's going to show up here come daylight. We don't even know what color they'll be (Horses 20).

Before he leaves San Angelo, John Grady seems unsure of himself and having a status of everlasting emptiness, but like most adolescents, he has been controlled by a search for meaning for his life. Through exile, John Grady attempts to break from his family identity, he seeks a new beginning that will open his eyes to a world outside his boyish understanding in which he enters into a world of obligation and responsibility. His country appears to be transformed into something he is not realizing. Thus, he sets out in order to make a new identity in his life as a cowboy.

\section{The Journey to the Foreign Land}

The journey to Mexico begins, however, as if John Grady and Rawlins were setting out into a world suddenly transformed. McCarthy suggests a promise of a new life beginning with the boys' departure from Mexico. As the journey begins, John Grady and Rawlins are described as "lined out behind one another and making for the alien shore like a party of marauders" (Horses 38).

Before entering Mexico, McCarthy implied the national identity in the borderlands. They passed by an American of Mexican origin who lives on the American side of the border and whom McCarthy ironically prefers to call as a Mexican. He seems much a product of the border as they are (Sugg, 2001, p. 199). Rawlins asked him: "You know that Country Down there?, The Mexican shook his head and spat. I have never been to Mexico in my life" (Horses 27). They find Mexico 'wild and strange', an 'alien world'. Then, what is down there has presented as alien in the incoming adventures.

Certainly, they frequently appear to go back in time as soon as they reached the border. Nevertheless, the separation between the two cultures is not always clear as the borderlands themselves are a place of hybridization, a place where the two cultures seem sometimes to have melded. For example, John Grady's capacity to change between binary dissimilar languages (Hage, 2010, p. 51).

This attachment to that lost cowboy world imprisons John Grady in a cyclic dependency on the restructured experience 
of the 'vanishing' cowboy. So, John Grady can never resolve the identity crisis to which he is attached. He has to move to Mexico to chase more cowboy life that would drive him to more crises of loss in the forthcoming days. This yearning for constancy in his life has a similar conflict with the modernizing world. This is the purpose why they go to Mexico, a place that they believe is 'symbolic of some lost time or imagined of the 'Old West'. James D. Lilley claims that the journey to Mexico is a "repeating of the American project itself, looking for a new beginning that reestablished itself with a forgotten past" (as cited in Campbell, 2010, p. 46).

Although, John Grady takes part in violence and bloody actions later, which is one of the great themes of the borderlands, for him, Mexico projects his notions of existence that followed the old cowboy codes. The critic Katherine Sugg (2001) suggests that for McCarthy's Anglo protagonists, this Mexican land offers the chances that were closed in the West by the time of World War II where open pastures were decreasing and cowboys begin to work in urban culture (p. 118).

When they come across Jimmy Blevins on the road, their enthusiasm to a new risky experience with ruthless consequences of their border journey is revealed. Then, Rawlins asks him why he rides with them? Blevins answers: "Cause I'm American." Here, the national identity plays a role in their acceptance to let him go with them, although they know that Blevins is a confused teenager who cannot take care of himself. He loses his horse and clothes in a thunderstorm. Then, he asks them to help him to recover his stolen horse.

John Grady does not take this quite seriously, and Rawlins supports his friend. Culturally, Rawlins shows the 'superiority' of the American character on the other nations by saying: "It damn sure dont belong to them Mexican." Then, John Grady and Rawlins help Blevins in the devotion of both their national and cultural identity. Moreover, on the psychological side, both Erikson and also Marcia agree that diffused youth is likely to engage in criminal acts. When they recover Blevins' horse, they separated from him after they were followed by Mexican men. However, the heroics cowboy codes that John Grady embraces, are the cause for his downfall, mainly his desire to help Blevins. This only contributes to his alienation and identity diffusion at the end of the novel.

Although All the Pretty Horses fits in the American tradition of fiction which portrays how young men defeat their difficulties in order to achieve moral growth, John Grady's journey to Mexico is to struggle for a cowboy culture that he wants to preserve it from fading away. However, his development requires an intersection that makes him realizes his personal usefulness. Yet, he continues to live according to the values which make his life an unrealistic one. What makes him confront the illusory nature of his heroic code is his experience with violence (Morrison, 1999, p. 175).

McCarthy constructs those cowboys who are lost because of what happens to their country. The more they feel isolated and alienated, the more they are faced with their own wasted meaningless existence. The alterations of the cultural and physical backgrounds of the West reduce their chances to survive in such setting. Fitting the developing identity, the first step must an individual make, is to assert his independence. This is what made those three young cowboys desert their homes and make their personal path (Scoones, 2001, p. 142).

However, violence, danger, and heroic deeds are the ingredients of a cowboy's identity that presented by tales of the bloody history of the Old West (Hage, 2010, p. 25). John Grady recognizes the passing process of the crisis and learns that it occurs at the heart of human experience:

He lay a long time listening to the others breathing in their sleep while he contemplated the wildness about him, the wildness within (Horses 50).

John Grady is affected by the massive desert of Mexico, which leads him to self-examination. As the journey continues, he has a profound look inside himself in an effort to settle an identity in the changing world. He realizes that his current identity is what he wishes to be in the future as a cowboy living on a ranch (Leitner, 2008, p. 18).

He starts a journey which is representative of the Western type of journeys through the plains, deserts and the mountains of the border. But, he continues his journey of self-realization, conscious that he is trying to come back to the old and mythical cowboy life. He realizes at the end that such a coming back is difficult. Nevertheless, there is something heroic that is taken from the myth of The Old West in his journey which he is pursuing (Woodson, 2011, p. 42).

The boys meet on the road a group of Zacateros, cultivators of hay where the image that the boys had in mind of Mexico is shattered as they come across those Mexican "a rough lot, half dressed in rags, they smelled of smoke and tallow... and they looked as wild and strange as the country they were in." One can say that McCarthy emphasizes the differences between nations with the acknowledgment the fact that "one country is not another" (Horses 122).

Although Jose Limon applauds the novel's celebration of a sympathy between John Grady and Mexican-American community and applauds the crossing implied in the novel's switching between Spanish and English, but the novel is filled with the oppositions of contradictory and rival cultures of the Anglo, the Comanche and the Mexican (as cited in Morrison, 1999, p. 175).

The two cowboys think that they ought to bring back their vanished heaven of cowboys when they get jobs as vaqueros (cowboys) on the ranch of Don Hector (Horses 82). They drink coffee with some local vaqueros, for most of whom America is "the country to the north was little more than a rumor" (Horses 81).

\section{The Promised Heaven of Cowboys}

John Grady rapidly wins the appreciation and approval of the other cowboys for his skills with horses, taming sixteen 
horses in four days. While the situation is temporary, the fact that John Grady has gambled in his journey to Mexico is what makes him continues shortly creating his identity in a place that he is happy with.

The chance for advancement in his work is exposed, he planned to create an identity away from his motherland. The term 'identity crisis' describes young persons who are in search of identity or even anxiety that they feel when the face intersection in their lives, here one can see that John Grady is facing this intersection. He seizes the chance proposed by Don Hector to work permanently with stallions, an option to carry on establishing his identity as a cowboy. He appears to be happy with his own journey as a try to build the identity and the connections he departed from. But when Don Hector asks what he is doing in Mexico, he is not aware what he is trying to do at Don's ranch, then he replies: "I just wanted to see the country, I reckon" (Horses 96). His uncertainty clarifies his exact reasons in which he is now experiencing an identity crisis.

With a presumed father and an occupation as a cowboy guaranteed, John Grady starts a romantic affair with Alejandra. But, he does not realize that Alejandra (Don Hector's daughter) has linked herself with the modern world. This makes him unable to understand why she ultimately refuses his marriage proposal. While discussing her with Rawlins, he highlights the point that he has not yet achieved to himself an identity in a foreign land (Sullivan, 2001, p. 241).

The relationship between John Grady and Alejandra represents a complex relationship of forces, especially that of the nation. Alejandra is the projection of her country (Mexico) in which people differ from that the people of the USA and that's what an identity means. John Grady finds what he did lose in America, he finds his dream of pastoral life at the hacienda working with horses and riding them through the landscape with his friend and falling in love with Alejandra. Here, the novel reflects the allegories of the $20^{\text {th }}$ century where frontier life is being the last castle against progress in the wilderness. The myth of the Old West, then, include the dispossessed of the last cowboy and the frontier (Guillemin, 2001, p. 93).

Soon, after his relationship with Alejandra, John Grady realizes the differences between the two nations and their cultures in regard to honor and women. As with most adolescents who have no commitment to a set of goals and beliefs, Alejandra ignores all the social norms of her family by sleeping with a man. Her aunt Alfonsa forbids their relationship, and tells John Grady:

I want you to be considerate of a young girl's reputation... You must understand. This is another country. Here a woman's reputation is all she has... There is no forgiveness. For woman. A man may lose his honor and regain it again. But a woman cannot. She cannot (Horses 115).

Then, John Grady is defying the cultural superego in sleeping with Alejandra. The aunt, Alfonsa, reveals that John Grady cannot marry her niece Alejandra because he does not understand the cultural difference between the two countries. The cowboy involves in a larger conflict of the cultural crisis in which John Grady finds himself involved with Alejandra and the aunt rejects him because he is "from another country" (Canfield, 2001, p. 263).

When Jimmy Blevins, their momentary friend, murders a Mexican man in a neighboring town, the Mexican police chase John Grady and Rawlins to the ranch. Don Hector finally gives them to the police when he knows of his daughter's relationship with John Grady. At that point, they depart from the Mexican ranch, and this marks a great change in their tendency towards the journey.

Their first challenge that marks the significance of the national identity came when the Mexicans execute Blevins in the wilderness. In doing so, McCarthy expresses the modern uncertainty about the ways in which contemporary society enacts technological and social means (Yee, 2010, p. 52).

Moreover, during their imprisonment in Saltillo, they involve in continuous violence for their survival as when they both barely survived a knife fight with other prisoners. While in recovery, Rawlins admits that he received a blood transfusion: "they put Mexican blood in me." He is worried because a liter of Mexican blood may somehow change his American nationality. In this regard, John Grady jokes with him saying: "Well a liter would make you almost a halfbreed. No. Hell, it don't mean nothing. Blood's blood. It dont know where it come from" (Horses 177).

This struggle for survival culminates in a knife fight between John Grady and a young cuchillero (cutler). John Grady kills his attacker by bringing his knife and sinking it into the cuchillero's heart. Although he kills him in self-defense, he finds himself haunted by it for the rest of the novel. "He'd of done it to you," Rawlins says in an attempt to comfort him. "You don't need to try and make it right. It is what is," John Grady responds (Horses 181). Because of his concern over his ability for violent acts, John Grady struggles morally to maintain his actions in the frame of the stable cowboy identity that he is trying to make for himself.

McCarthy characterizes John Grady as an adolescent whose male flesh is violated. The cowboy culture describes the cultural inversion of involuntary bleeding in any form because this culture requires the professional skill and strategic application on the part of the surgeon and self-mastery on the part of the patient and here John Grady has done them both. In Western novels, the image of the male body violated often develops a process of slow recovery that leads to renewed strength (Sullivan, 2001, p. 243).

So, John Grady has self-devastating tendencies in which he has no obligations towards himself or others. In his struggle towards a cowboy dying culture, as he was always preoccupied with the loss of the Old West, he has a sense of confusion in life since childhood. It is evident that his crisis turns around the passing culture of the Old West where McCarthy has implied this sense of loss in John Grady's loss cowboy way of life (Sugg, 2001, p. 118). 
There is also a profound significance to the indication of the borderlands where the protagonists usually appear to be composed of two cultures or in that neither county in which the boundary is fixed between existence and extinction. One can see the fading and the growing of cultures and of lifestyles in the novel (Hage, 2010, p. 24).

\section{Passing Adolescence}

On the condition that Alejandra promises not to see John Grady anymore, Alfonsa arranged their release from the prison. He insists on pursuing Alejandra which leads him back to the La Purisima. Absolutely depressed and diffused after he met Alejandra for the last time in which he failed to convince her to accept his marriage proposal, John Grady thinks that the crisis of loss of Alejandra will be his permanent status in life. His confusion status over the loss of Alejandra makes him thinks of his history of past crises:

He saw very clearly how all his life led only to this moment and all after led nowhere at all. He felt something cold and soulless enter like another being and he imagined that it smiled malignly and he had no reason to believe it would ever leave... What he had not known was that it was mindless and so had no way to know the limits of those souls and what he feared was that there might be no limits (Horses 214).

This is the modification of one's identity to fit his situation. Here, McCarthy reveals the effects of the psychological phases of the crisis of loss upon John Grady as his faith in himself fades away. In the night, John Grady avoids any human connection because of his crisis and he tries to think where he has mistaken. He laid there deprived of any solid base upon which he can form a stable identity from his experience: "He slept that night in a field far from any town. He built no fire... and he listened to the wind in the emptiness" (Horses 214). Here, one can understand John Grady's detachment from society which causes him further crisis. Alejandra provides him with a sense of what it means to keep on living and to look forward to being in the world, but as he finally lost her, he senses abandonment in the world with no place to go.

These effects go beyond his youthful recognition of the crisis that he bears in Mexico. Unable to articulate his own damaged identity, he cannot make up any others, and this sense of confusion comes to be an essential feature of his life, the one thing which links him with the world: "as he lay there the agony in his heart was like a stake" (Horses 214).

Then, the novel takes a twist as John Grady starts to seek vengeance from the Mexican captain who killed Blevins, rather than seeking the cowboy way of life he loves. At first, it seemed that John Grady might kill him to revenge for his injuries, and Rawlins's and the death of Blevins but he returns to recover the horses. This scene culminates when he manages to rescue the horses that belong to him, to Rawlins and Blevins and he takes the captain as hostage.

Alone on the borderlands in the village of Los Picos, after he survives these dangerous encounters, John Grady has visibly flown the edge of danger. Then, a change is displayed in John Grady's personality since he left Texas. Earlier, John Grady's idealism has no limit, but here one can see that he recognizes the limits that range outside youth and affect the identity of each individual. After rescuing the horses, his status transfers from guilt of these youthful experiences to a kind of development in his character that is obvious now:

He remembered Alejandra and the sadness he'd first seen in the slope of her shoulders which he presumed to understand and of which he knew nothing and he felt a loneliness he'd not known since he was a child and felt wholly alien to the world although he loved it still. He thought that the world's heart beat at some terrible cost and that the world's pain and its beauty moved in a relationship of divergent equity (Horses 235).

One can describe a developing young man who attempts to settle the past with the present, in terms of finding a meaning in his experiences. As he realizes the connection between people, John Grady senses the individuality of his life. Still, he reaches to view life as a place which causes the suffering that symbolizes the human crisis.

The following day, John Grady has a new crisis, namely, the loss of his father: "when he woke he realized that he knew his father was dead." When he finally returns from Mexico, he continues to feel lost: "a loneliness he'd not known since he was a child and he felt wholly alien to the world although he loved it still," (Horses 235). His crisis of loss increases as he grieves the death of his nanny "Abuela", he appears to realize the sacrifices of others and their effect on his identity. The loss of his major advisors in his family pushes him to admit that the meaning of his life is determined by the meaning he shares with others (Hage, 2010, p. 101).

Nevertheless, he appeared in the court of law in Texas, where conveys his story, this helps as an additional phase in the development of a settled identity. John Grady struggles to establish a complete identity that comprises the crossing of his confusion status from moments of responsibility and connections among people. The judge rules in John Grady's favor, he identifies the latter's maturity by the judgments of the law (Arnold, 2001, p. 71).

Later, John Grady tells the story of his recent adventure to the judge, that makes him inquire his own journey. The adolescent's psychological struggle contributes to his desire to make a stable identity. Thus, Mexico does not offer the longed for pastoral life for John Grady, who has the self-perception as brave and chivalrous, as he was accepting the ideals of cowboy culture that collapsed. He cannot continue living as a cowboy if he is unable to settle his passion as the man he seeks to be. His journey into Mexico ends and it echoes his identity crisis as he laments the loss of the 'country' that cannot be brought back as its culture died. He keeps that sense of permanent crisis that worried him at the beginning of the novel. He returns home, but only to confirm his continuing status as a restless wanderer looking for a 
lost 'country' (Guillemin, 2001, p. 95).

Jay Ellis (2006) records such restlessness in McCarthy's characters and suggests that it condemns the individual to loneliness and perpetual yearning for a completion and fulfillment that is unattainable. The future for John Grady once more involves leaving out the country of his childhood where he no longer feels that he belongs to (p. 264). The final conversation between John Grady and Rawlins sums up the effects that the trip had on him:

John Grady: I think I'm going to move on.

Rawlins: This is still good country.

John Grady: Yeah. I know it is. But it aint my country.

Rawlins: Where is your country?

John Grady: I don't know. I don't know where it is. I don't know what happens to country (Horses 250).

Here, the idea of "country" seems to highlight John Grady's region as well as the larger sense of the "nation". He is implying that he does not belong to his birth country, and also indicating that the culture of the Old West that he sought on his journey to Mexico has lost. All what is left for him to head out once more (Hage, 2010, p. 27).

McCarthy offers a grim variation on quest themes, one in which is the identity crisis. One can see that John Grady is not only coming back passionately bare hands after his trip to Mexico, but he is also unable to find the national identity, he has before "I don't know where (my country)." When his friend Rawlins suggests that he may stay in Texas and get a job in an oil Company, his reaction indicates the chasing of the myth of Western open space. If one asks what does John Grady means by "country?" One definition suits McCarthy's characters that a "country" is a region, territory, or a large tract of land that can be distinguished by cultural features. For example, when he rides across the border territory, he realizes the mix of cultures of the American West and Northern Mexico (Ellis, 2006, p. 180).

Benedict Anderson says in his book Imagined Communities (1991), that national identity is not continuous in these limited border areas and recorded as a simple device and this attitude resounds in the Border Trilogy as well. However, it is not merely the "country" but also the lifestyle and methods of survival that are submitted to the temporary nature of the borderlands. All the Pretty Horses moves through crucial changes that crushed the cultures of the region in which massive open deserts and plains are occupied with railroads and divided into ranches and the ranches one by one are bought to turn them into oil fields. By the first thirty years of the $20^{\text {th }}$ century, some of the small "cattle towns" developed into cities and the heart of the oil industry in the USA. "The vast cattle country was opened to the petroleum industry." By the time of John Grady, the oil industry had a strong position in the cowboys' lands and their way of life was quickly fading (p. 33).

In these scenes, McCarthy sets the ways in which the deep misery embodied in such ways that impact the character developing identity. Additionally, John Grady's growing awareness of the declination of pastoral life is reflected in his sense of confusion. He struggles against the changing world:

Perhaps as if to slow the world that was rushing away and seemed to care nothing for the old or young or rich or poor or dark or pale or he or she. Nothing for their struggles, nothing for their names. Nothing for the living or the dead (Horses 251).

An uncertain path is his future, but it also a path directing him to the previous lifestyle of the Old West. It is a journey marked by his association, once more, with the Comanche tribes of the past, a suggestion of how John Grady's storyline has also reached its full circle (Beck, 2009, p. 131).

McCarthy makes implicit historical cycles of nation-building on violence as the USA was built on the blood of the Native Americans as did the Native before. This suggests that Cowboys are fading as the Indians. This passage below echoes the scene of the Comanche trail ride which is previously mentioned in the novel and suggests the bloody history of the past:

The Indian stood watching him. He could see that none of them spoke among themselves or commented on his riding there nor did they raise a hand in greeting or call out to him. They had no curiosity about him at all. As if they knew all they needed to know. They stood and watched him pass and watched him vanish upon that landscape solely because he was passing. Solely because he would vanish (Horses 251).

McCarthy emphasizes John Grady's naivety concerning his vision of the Indians. It could be suggested that this vision of vanishing Indians is reversed at the end of the novel as the Indian watch him vanished while he "passed and paled into the darkening land", his future is assured in the world to come (Morrison, 1999, p. 179).

John Grady's crisis sets up the heroic archetype journey of the novel which moves John Grady, according to Morrison, towards his final journey back home, no longer a naive person, but a man who is deepened and enriched by experience (p. 191). Yet, McCarthy's Comanche comparison suggests that while John Grady's may evoke the epic journey of the Western tradition, it may also be doomed to failure as the Comanche because of the loss of the community and culture in which his individual superiority flourishes (Snyder, 2001, p. 205). 
The mid of $20^{\text {th }}$-century background of the Border Trilogy hints at the collapse of the cowboy ranching culture which is started by "the inheritors of the $19^{\text {th }}$-century expansionists." This constructed backwardness for the increasingly outmoded cowboy culture and to characterize the disability of that community that is illustrated in McCarthy's novels (Beck, 2009, p. 16). The lost pastoral life of the cowboys which strikes a nostalgia, and the drought that plagued Western landscapes are shown in the novel:

In the evening a wind came up and reddened all the sky before him. There were few cattle in that country because it was barren country indeed yet he came at the evening upon a solitary bull rolling in the dust against the bloodred sunset like an animal in sacrificial torment. The bloodred dust blew down out of the sun (Horses 252).

The Failure of John Grady's journey is shown through the Native Indians who are terminated a century ago. Modernity threatened the cowboy lifestyle through the arrival of technology in the $20^{\text {th }}$ century. All the Pretty Horses ends with the disillusioned cowboy riding:

With the sun coppering his face and the red wind blowing out of the west across the evening land... horse and rider and horse passes on their long shadows passed in tandem like the shadow of a single being. Passed and paled into the darkening land, the world to come (Horses 252).

In this passage, McCarthy invokes the symbolic image of the cowboy riding through the vast plains before vanishing into "the darkening land." However, the end of the history of the cowboy is anticipating as modernity is still affecting the frontier. Then, it is John Grady, not the Indians, who represents the vanishing American West and the decline of the cowboy way of life. He originally departs from Texas so that he can develop and make his identity in a location similar to his home. But in fact, while he was trying only to make an identity there, he discovers that his accomplishment in Mexico was brief. Upon his reappearance in Texas, he has tested different identities: cowboy, a lover, a fighter, and a diplomat. Although his opinion of home is transformed because of this process, his original wish to restore the cowboy culture of the past stays a powerful force for the story (Peebles, 2011, p. 51).

\section{Conclusions}

John Grady fails to construct a settled identity due to an inability to confirm a sense of the self. McCarthy shows that experiences do not only have the ability to ruin one's predetermined views of the self and the world, but they certainly help one to build an identity in response to these moments of crisis. The major transformation in John Grady's personality results from his own experiences of violence and personal loss that correct his way of seeing the world. As an adolescent who develops his sense of the self in the ranching community that collapses, his story conveys the meaning of identity crisis in McCarthy's model of development.

Even after he becomes conscious of the crisis of loss and its effects on him, John Grady did not maintain a complete identity for himself. All of this does not alter his immature identity as well as continuing diffused status. His story portrays the crises as the foundation upon which one makes sense of life experiences, and the response to these crises determines the identity.

He represents the self-realization in cowboy culture in which excellence, isolation, and independence are the basics of a cowboy identity. This identity also depends on relationships formed in a familial community without which the Western individuality would be incomplete. John Grady's obsession with recovering and returning to what has been lost, whether horses or people or lifestyle, can be seen as reflecting this sense of psychological and cultural crisis within himself.

\section{References}

Arnold, E. T. (2001). "Go to Sleep: Dreams and Visions in the Border Trilogy." A Cormac McCarthy Companion: The Border Trilogy. Ed. Edwin T. Arnold \& Dianne C. Luce. Jackson: University Press of Mississippi.

Anderson, B. (2006). Imagined Communities: Reflections on the Origin and the Spread of Nationalism. London: Verso.

Beck, J. (2009). Dirty Wars: Landscapes, Power, and Waste in the Western American Literature. Lincoln: University of Nebraska.

Cameron, J. M. (2011) Border Wars and Armageddon: Contemporary American Literary Naturalism in Cormac McCarthy's Western Novels. USA: Georgetown University.

Canfield, J. D. (2001). "Crossing From the Wasteland into Exotic in Cormac McCarthy's Border Trilogy." A Cormac McCarthy Companion: The Border Trilogy. Ed. Edwin T. Arnold \& Dianne C. Luce. Jackson: University Press of Mississippi.

Campbell, N. (2010). "The Western." A Companion to Twentieth-Century United States Fiction. Ed. David Seed. Chichester, U.K: Wiley-Blackwell Publishing Ltd.

Deaux, K. (2000). "Identity." Encyclopedia of Psychology: Volume 8, section IV. Ed. Alan E. Kazdin. Washington, D.C.: American Psychological Association.

Dary, D. (1989). Cowboy Culture: A Saga of Five Centuries. Lawrence: University Of Kansas Publishing. 
Ellis, J. (2006). No Place for Home: Spatial Constraint and Character Flight in the Novels of Cormac McCarthy. Ed. William E. Cain. New York: Routledge: Taylor \& Francis Group.

Guillemin, G. (2001). "As of some site where life had not succeeded: Sorrow, Allegory, and Pastoralism in Cormac McCarthy's Border Trilogy." A Cormac McCarthy Companion: The Border Trilogy. Ed. Edwin T. Arnold \& Dianne C. Luce. Jackson: University Press of Mississippi.

Hopkins, J. R. (2000). "Erikson, Erik H." Encyclopedia of Psychology: Volume 8, section III. Ed. Alan E. Kazdin. Washington, D.C.: American Psychological Association.

Hage, E. (2010). Cormac McCarthy: A Literary Companion. Jefferson, N.C.: McFarland \& Company.

Inness, J. (2000). Cliffsnotes on McCarthy's All the Pretty Horses: Notes. Lincoln, Nebraska: Cliffsnotes.

Jackson, G.A. (2010). The Meaning of Pain in Cormac McCarthy's Border Trilogy. Missoula, Montana: University of Montana.

King, M. (2012). Unattainable Manhood: Masculinity and Folk Culture in late $20^{\text {th }}$ Century American Fiction. USA: University of Illinois at Chicago.

Leitner, W.H. (2008). Naturalistic Determinism in the Border Fiction of Cormac McCarthy. USA: The University of Georgia.

McCarthy, C. (1992). All the Pretty Horses. Volume One: The Border Trilogy. USA: Vintage International: A Division of Random House, Inc.

Morrison, G.M. (1999) "All the Pretty Horses: John Grady Coole's Expulsion from Paradise". Revised Ed. Perspectives On Cormac McCarthy Southern Quarely Series. Ed. Edwin T. Arnold \& Dianne Luce. Rev. ed. Jackson: University of Mississippi.

Peebles, S. (2011). "Hang and Rattle: John Grady Cole's Horsebreaking in Typescript, Novel, Film." Cormac McCarthy: All the Pretty Horses, No Country for Old Men, The Road. Ed. Sara L. Spurgeon. London: Continuum International Publishing Group.

Rodriguez, M. Y. (2014). "Relocating the Cowboy: American Privilege in All the Pretty Horses." Vol. 8. USA: Global Tides. Web. http://digitalcommons.pepperdine.edu/cgi/viewcontent.cgi?article=1135\&cont xt=globaltides. Feb 5, 2015.

Shaffer, D. R. (2007). "Identity Crisis." Encyclopedia of Social Psychology. Ed. Roy F. Baumeister, Kathleen Vohs. Thousand Oaks, Calif.: Sage Publications.

Scoones, J. (2001). "The World on Fire: Ethics and Evolution in Cormac McCarthy's Border Trilogy." A Cormac McCarthy Companion: The Border Trilogy. Ed. Edwin T. Arnold \& Dianne C. Luce. Jackson: University Press of Mississippi.

Snyder, P. A. (2001). "Cowboys Codes in Cormac McCarthy's Border Trilogy." A Cormac McCarthy Companion: The Border Trilogy. Ed. Edwin T. Arnold \& Dianne C. Luce. Jackson: University Press of Mississippi.

Sullivan, N. (2001). "Boys Will Be Boys and Girls Will Be Gone: The Circuit of Male Desire in Cormac McCarthy's Border Trilogy." A Cormac McCarthy Companion: The Border Trilogy. Ed. Edwin T. Arnold \& Dianne C. Luce. Jackson: University Press of Mississippi.

Spurgeon, S.L. (2009). "Foundation of Empire: The Sacred Hunter and the Eucharist of the Wilderness in Cormac McCarthy's Blood Meridian." Bloom's Modern Critical Views: Cormac McCarthy. Ed. Harold Bloom. New ed. New York, NY: Bloom's Literary Criticism.

Sugg, K. (2001). Multicultural Masculinities and the Border Romance in John Sayles's Lone Star and Cormac McCarthy's Border Trilogy. USA, Michigan State University Press.

Woodson, L. (2011). "This is another Country: The Complex Feminine Presence in All the Pretty Horses." Cormac McCarthy: All the Pretty Horses, No Country for Old Men, The Road. Ed. Sara L. Spurgeon. London: Continuum International Publishing Group.

Yee, Ch. (2010). The Salitter Drying from the earth: The Apocalypse in the novels of Cormac McCarthy. New Zealand: University of Canterbury.

\section{Note}

This paper is a part of the author's M.A. thesis entitled "Identity Crisis in Cormac McCarthy's Border Trilogy" written at the University of Al-Qadisiya, College of Education, Department of English. 